\section{The Compleat Philosophy Librarian}

\section{Wayne Bivens-Tatum, Guest Columnist}

\author{
Correspondence concerning this \\ column should be addressed to Neal \\ Wyatt, The Alert Collector, c/o RUSA, \\ 50 E. Huron, Chicago, IL 60611; e-mail: \\ alertcollector@comcast.net.Wyatt is \\ a collection development and readers' \\ advisory librarian from Virginia. She \\ wrote The Readers' Advisory Guide \\ to Nonfiction (ALA Editions, 2007), \\ is the editor of Library Journal's \\ "Reader's Shelf" column, author of \\ Booksmack!'s "RA Crossroads" whole \\ collection RA column, and compiles \\ LJ's weekly "Wyatt's World Lists."
}

Wayne Bivens-Tatum is the Philosophy and Religion Librarian at Princeton University.
Philosophy can be considered one of the "key" subjects, unlocking as is does much of the theoretical conversations that take place in other fields. It can also be a daunting proposition for librarians trying to develop a collection that is broad enough to capture the subject, yet deep enough to take users beyond a rudimentary level. Wayne Bivens-Tatum, the philosophy and religion librarian at Princeton University, offers a guided tour through the possibilities and must-have's of a basic collection with advice for public librarians and advanced graduate subject specialists. With an expert voice and comforting reassurance, Bivens-Tatum examines the resources and explains not just what to collect but what makes each title useful. Readers who enjoy his clear insight can read more of his ruminations on libraries, reference, and the humanities on his Academic Librarian blog available at academiclibrarian .net. He can be reached at rbivens@princeton.edu._Editor

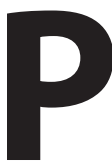

hilosophy as an area of study is both circumscribed and limitless. As studied in American colleges and universities, philosophy is a very focused field. However, every subject has a philosophical aspect, and some use the term philosophy to mean an entire worldview. In this review, I am limiting myself to philosophy as it is studied in the majority of philosophy departments at AngloAmerican universities, that is, the Western philosophical tradition beginning with the ancient Greeks and developing as a more or less coherent body of thought revolving around a family of common questions.

Philosophers, like most scholars in the humanities, rarely seek research help from librarians. There are several reasons for this. First, rather than gather immense amounts of data or read large numbers of books and articles for their research, philosophers tend to analyze a few sources and arguments in great depth. Except for historians of philosophy, philosophers rarely need to do exhaustive searches for information or esoteric archival work because most of what they study is contained in a few books and journals with which they are already familiar. Students of philosophy are usually trained in philosophical analysis and are guided by their professors to both methods and sources of analysis.

Another possible reason that philosophers and philosophy students need less research help is because, for a relatively compact discipline, philosophy has a remarkably robust bibliographic and reference apparatus, and sources are easy to find. The major index to the field is quite good and has competition. There are three major encyclopedias vying for attention, as well as a host of excellent reference tools developed by Oxford, Cambridge, and Blackwell presses among others. 
In this column, I will address some major tools in philosophy reference, focusing on English-language resources. A librarian with access to all these resources should be able to address almost any research need in philosophy, as well as be able to identify philosophy titles necessary for purchase to build a comprehensive collection. I am including all the sources I consider necessary for a basic, solid philosophy reference collection, but I will note throughout what are essential for different levels of philosophy support.

\section{PHILOSOPHY LITERATURE}

Philosopher's Index (http://philindex.org)

The Philosopher's Index bills itself as the "world's most current and comprehensive bibliography of scholarly research in philosophy," and that is undoubtedly true. It has been the standard index for philosophy literature for decades. It indexes over 680 journals and claims to have over 450,000 records. Though it began in 1970 , retrospective indexing goes back to 1940. It is published by the Philosophy Information Center and is available by subscription online through Ebsco, OCLC, Ovid, and ProQuest. If your library supports a philosophy department, this is a necessary index.

Philosophy Research Index (www.pdcnet.org)

This index is brand new and is designed to compete with the Philosopher's Index. At the moment, it indexes 360 journals in multiple languages, but its ultimate goal is to provide extensive bibliographic coverage of philosophy comparable to or exceeding the Philosopher's Index and at a much better price. (The Philosopher's Index was originally published by the Philosophy Documentation Center (PDC). However, the copyright was owned by Richard Lineback, and when he left the PDC in 1995 he took the Philosopher's Index with him.) The PDC publishes numerous journals and tools, and with Intelex publishes POIESIS: Philosophy Online Serials, which provides searchable digitized content for journals otherwise available only in print. The Philosophy Research Index could eventually become the major index for philosophy. It currently claims to have 650,000 citations, which is more than the Philosopher's Index, but in several subject searches I tried, the Philosopher's Index came up with more and better results. For the time being, the Philosopher's Index is still the top index.

\section{PhilPapers (http://philpapers.org)}

PhilPapers is a directory of online philosophy articles and books. Philosophers can submit entries, but it also automatically crawls 309 online journals, as well as articles posted to the websites of about 1,900 philosophers. Your library must have a subscription to access many of the journals, but it also links to open-access journals, online archives, and papers on philosophers' personal websites. Thus, it will not only have citations included in the Philosopher's Index and the Philosophy Research Index but preprints and other typically unindexed material. It currently claims to have 305,000 entries.
Intelex Past Masters (http://pm.nlx.com)

Past Masters from Intelex can provide online full-text access to critical editions of the works of many major figures in the history of philosophy from Plato to Pierce, sometimes both in their original language and in English translation. Each title is a standalone purchase based on FTE, with a low yearly access fee and discounts after a certain amount has been spent. Larger libraries may want to purchase the complete works of Descartes, Hegel, Kant, Nietzsche, and Wittgenstein in their original languages. But even smaller libraries could benefit from smaller anthology collections such as The Continental Rationalists and British Philosophy 1600-1900.

\section{PHILOSOPHY REFERENCE}

\section{Dictionaries}

Audi, Robert. The Cambridge Dictionary of Philosophy, 2nd ed. Cambridge: Cambridge University Press, 1999 (ISBN: 978052-163136-5).

Honderich, Ted, ed. The Oxford Companion to Philosophy. 2nd ed. Oxford; New York: Oxford University Press, 2005 (ISBN: 978-019-926479-7). (Also available in Oxford Reference Online.)

Every reference collection should have a dictionary of philosophy or two, and every librarian who collects for philosophy or works with students should have one handy. There are dozens of dictionaries of philosophy available, but I've listed the two best. My favorite is The Oxford Companion to Philosophy. Like most other entries in this series, The Oxford Companion to Philosophy is an excellent single-volume reference work. It has short entries on most areas of philosophy, as well as biographies of many philosophers. Robert Audi's Cambridge Dictionary of Philosophy is similar, with some longer entries, and more coverage of non-Western thought. Libraries that can afford to should purchase both titles.

\section{Encyclopedias}

Borchert, Donald M., ed. Encyclopedia of Philosophy, 2nd ed. Detroit, Mich.: Macmillan, 2006. (ISBN: 978-002-865780-6). (Also in Gale Virtual Reference Library.)

Craig, Edward, ed. Routledge Encyclopedia of Philosophy. London: Routledge, 2000. (ISBN: 978-041-507310-3). (http:// www.rep.routledge.com)

Zalta, Edward N., ed. Stanford Encyclopedia of Philosophy. Stanford, Calif.: Metaphysics Research Lab, Center for the Study of Language and Information, Stanford University, 1995. (http:// plato.stanford.edu)

Philosophy is unusual in having three major, comprehensive encyclopedias competing to cover a relatively focused, though 2,500-year-old, field. All three are excellent in their way. The Encyclopedia of Philosophy is the 2nd edition of the 1967 Encyclopedia of Philosophy edited by Paul Edwards. The older edition was the standard for thirty years and is widely available in libraries. For some historical topics the 
older edition is still sometimes useful, but the 2nd edition is completely revised and current. It has longish articles with extensive bibliographies written by experts on every area of philosophy. It is also available online through the Gale Reference Library, but the print volumes are recommended if online is too expensive.

The same cannot be said of the Routledge Encyclopedia of Philosophy. The Routledge Encyclopedia is outstanding and comprehensive, but while it was first designed as a print encyclopedia, it lives more naturally online. The entries tend to be shorter than the Encyclopedia of Philosophy, with many cross-references. In print, this means you really need all ten volumes in front of you, whereas online those cross-references become hyperlinks, making the Routledge Encyclopedia very web-friendly. Online, the entries are updated quarterly. The articles are written by experts in the field and contain excellent bibliographies. Highly recommended.

The Stanford Encyclopedia of Philosophy is possibly the best open-access reference work. It started under NEH grants and is now partially funded by an endowment created through contributions by libraries and philosophy departments all over the world. Expert philosophers are commissioned to write the entries, which are very in-depth with extensive bibliographies. It is not as comprehensive as the other major encyclopedias, partly because it is still a work in progress (commissioned but unfinished entries are included but have no content). Nevertheless, the content there is excellent, and it is freely available.

I have emphasized the bibliographies of these encyclopedias because for collection development purposes they are invaluable, especially if your library has no philosophy approval plan. Though it is relatively inexpensive to provide decent coverage for philosophy as it is practiced in mainstream philosophy departments (possibly twenty publishers and a hundred or so journals publish most of the content that most philosophers write and read), not all libraries will want even this minimal coverage. Others will want to make sure that subcategories of philosophy are well covered at their libraries, and the major entries in these encyclopedias will provide good checklists for books to collect, whether critical editions of historical philosophers in the original languages and translation or key titles for newer topics that might be of interest. (For free examples of useful bibliographies for collection development, see the Stanford Encyclopedia of Philosophy entries on "Cosmopolitanism" or "The Moral Status of Animals.")

Most college, university, and mid- to large-sized public libraries should probably have the Encyclopedia of Philosophy or the Routledge Encyclopedia in print at the very least and preferably have both print and online versions. If your library is supporting a philosophy department, having at least one of them online is very useful. For others, the Stanford Encyclopedia alone might suffice, and you cannot beat the price.

\section{Guides, Summaries, and Bibliographies}

Blackwell Philosophy Companions, Guides, and Anthologies Blackwell's philosophy reference collection is outstanding.
At the time of writing, there are a hundred or so Companions and Guides relevant to philosophy. Each entry in those two series is a solid, thorough introduction to, and overview of, the topic at hand. Though there are a handful of guides to major philosophers such as Kant or Nietzsche, the bulk of both series cover major philosophical fields (ethics, epistemology, metaphysics, etc.) as well as prominent sub-fields (such as bioethics or medical ethics). The separate articles within the Companions and Guides are lengthy with extensive bibliographies. I would consider the print volumes of most of the Blackwell titles essential for any library supporting even an undergraduate program in philosophy. Some are more basic than others, and for the most basic collection, the Companions to epistemology, metaphysics, and ethics, for example, would be more necessary than the Companions to early modern philosophy or Christian ethics, but I would recommend any that are relevant to your users. Most of the titles are available via subscription in the Blackwell Reference Online database, if that's an affordable option. Blackwell Reference Online has one of the strongest humanities reference collections available. Though not reference titles as such, the corresponding Blackwell Anthologies make excellent complements to the Companions and Guides. A student interested in contemporary ethics, for example, and armed with the Blackwell Guide to Ethical Theory, the Companion to Ethics, and Ethical Theory: An Anthology, would be well prepared to begin serious study.

\section{The Cambridge Companions to Philosophy}

The Cambridge Companions to Philosophy, Religion, and Culture series (of which about seventy-five or so titles are relevant to philosophy) provide excellent introductions to most major philosophers and some philosophical movements. Each volume has a series of essays on important areas of the philosopher's work as well as useful bibliographies. If a student was interested in an area of philosophy such as ethics or aesthetics, I would suggest the relevant Blackwell Companion or Guide, but if a student was interested in a particular philosopher, I would suggest the Cambridge Companions. The two series complement each other well. The Cambridge Companions are available online via subscription through the Cambridge Collections Online database. The print volumes are essential for any library supporting classes in philosophy, but the online volumes are very handy to have for larger libraries.

Roth, John K., Christina J. Moose, and Rowena Wildin. World Philosophers and Their Works. Pasadena, Calif: Salem Press, 2000 (ISBN: 978-089-356878-8).

World Philosophers and their Works is Masterplots for major philosophers. The five volumes in this set provide extensive summaries, bibliographic essays, and lists of further reading for more than two hundred major works of philosophy. If you want a good, clear introduction to the main ideas and major themes of Aristotle's Nicomachean Ethics or Kant's Groundwork of the Metaphysics of Morals, this is a good place to go. I would recommend it from upper high school through undergraduate 
use or for general readers who want to explore some philosophical classics. There's an out-of-print 1982 set with more or less the same content, World Philosophy: Essay-Reviews of 225 Major Works, also from Salem Press. Most libraries could get by with either edition, especially since more current bibliographies are usually available in the encyclopedias.

Oxford Bibliographies Online (www.oxfordbibliographies online.com)

Oxford Bibliographies Online is another new product and is Oxford University Press's first publication created only for the Internet. There are several modules available. The philosophy module currently has fifty-nine entries, ranging from broad topics like "Epistemology" to narrower topics like "Rule-following" or "Semantic Externalism." Each entry is a lengthy annotated bibliography covering the major books and articles in the area. The organization and annotations are very well done, and the individual citations link to link-resolvers and Worldcat.org, and users can export citations or save them if they create an $\mathrm{OBO}$ account. A bibliography on a relevant topic would give an advanced student a full representation of the most important works to read and a librarian a list of the most important works to buy. If your library supports a philosophy graduate program, this resource is almost essential.

\section{PHILOSOPHY BOOK REVIEWS}

Notre Dame Philosophical Reviews. (http://ndpr.nd.edu)

Notre Dame Philosophical Reviews is a great source for reviews of philosophy books. Edited by a couple of philosophers at Notre Dame, NDPR has published a dozen or two book reviews every month since January 2002. The reviews are 1,500-2,000 words. NDPR could be valuable for philosophy students wanting to know more about a book before they read it, but for librarians its greatest use is probably for collection development. Because the reviews usually appear within six to twelve months of the book's publication, they are timely, and the books they review should still be easily available. You can visit the site or sign up for an e-mail list.

\section{CONCLUSION}

If you want to be able to help users find literature on philosophical topics but have absolutely no money to spend, the two free resources on this list will go a long way. Between PhilPapers, the Stanford Encyclopedia of Philosophy, and possibly WorldCat.org, library users should be able to get a basic overview of many philosophical topics and a recommended list of reading, if not the sources themselves. As with most fields in the humanities, if you can identify a recent and relevant work or two from a solid journal or good scholarly press, then you should stop searching for a while and start chasing footnotes. PhilPapers and the Stanford Encyclopedia have thousands of current articles and recent bibliographies between them.

If you're in a large public library with a philosophy reference collection, you can do a good job at general reference with relatively little cost. The Stanford Encyclopedia of Philosophy is free online. This should be supplemented with either the Encyclopedia of Philosophy or the Routledge Encyclopedia of Philosophy (depending on the price). The Oxford Companion to Philosophy is useful and inexpensive as well.

For academic libraries, the recommendations depend on the scope of the philosophy department and the library budget. If it's a small department with no graduate program, I would recommend the Philosopher's Index, supplemented by the free PhilPapers. A healthy selection of Companions by Cambridge and Blackwell would also be good. Though philosophers get to most of their sources through other sources, occasionally they will need the standard index for their field. At least one of the major philosophical encyclopedias other than the Stanford Encyclopedia is a necessity, and both would be preferable.

For larger academic libraries and philosophy departments with graduate programs, the minimum desirable collection would include the Philosopher's Index, all three of the major encyclopedias (though not necessarily all online), Oxford Bibliographies Online, the Cambridge Companions to philosophy, and the Blackwell philosophy Companions, Guides, and Anthologies.

I have deliberately focused on what I see as a core collection and have ignored a wide range of philosophy reference works, including works in languages other than English and works about non-Western philosophy. Most academic libraries should stock a range of more specialized works, such as Becker's three-volume Encyclopedia of Ethics (2nd ed. Routledge, 2001) or Post's five-volume Encyclopedia of Bioethics (Macmillan, 2004), to name just a couple. For a comprehensive overview of philosophical reference works, see Hans Bynagle's Philosophy: A Guide to the Reference Literature (3rd ed. Westport, Conn.: Libraries Unlimited, 2006). Its 389 pages and 866 entries will take you more deeply into the philosophy reference literature than most libraries are ever likely to want or need to go. 